\title{
J(৫)
}

Received: 20.05.2020

Accepted: 30.05 .2020

Published: 14.06 .2020

JOTS, 4/2, 2020: 437-468

\section{Salur Kazan ve Yuvarlanan Taş Anlatısı Hakkında}

\section{About the Story of Salur Qazan and the Rolling Stone}

\author{
Aslihan HAZNEDAROĞLU \\ Düzce University (Düzce/Turkey) \\ E-mail: aslihankaragoz@duzce.edu.tr
}

Salur Qazan, who has a special place in our epic tradition, is the hero who has surrounded all the narratives of the Günbäd manuscript, which was unearthed in 2019 and introduced to the world of science. On the pages 38-39 of the manuscript, Qazan's heroism about the "holding the rolling stone" was explained in the soylama, which he expressed in his heroism. This narrative is a heroism of Qazan, which has been described as "epic stereotype" in Shejere-i Terākime, Topkapi Oyuzname and the Dresden manuscript of Dede Qorqut Book. It is also seen that this narrative has a reflection among the Altay Turks. The analysis of this narrative, which is full of uncertainties both in terms of the location of the event, the nature of the event and the parties of the event, is an important contribution to the uncovering the ground on which epics are fed. In this analysis, it is aimed to compare the text with parallel narratives and to reveal the similarities and differences between the texts and to reveal the scope of the text's expression.

Key Words: Dede Qorqut, Salur Qazan, Günbäd manuscript, Ala Čaqun Čolpa Day, the rolling stone, wine table. 


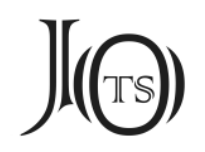

\section{Giriş}

Dede Korkut hikâyeleri içinde Salur Kazan en özel ve merkezî bir yeri olan kahramandır. Oğlu Uruz, eşi Burla Hatun'la, kayın atası olan hanlar hanı Bahadır Han, kardeşi Kara Göne ve hem yeğeni hem damadı olan Kara Budak ile akrabalık ilişkileri hikâyelerin birçoğunu kuşatmış olan Salur Kazan, Dresden ve Vatikan yazmasındaki on iki boyun dokuzunda da anılmaktadır. Salur Kazan'ın destanlarımız içindeki ağırlığı, ortaya çıkan yeni yazmada da görülmektedir. Bilim dünyasına Günbed, Türkmensahra, Türkistan/Türkmensahra nüshası gibi farklı isimlerle tanıtılan yazma, soylama ağırlıklı bir metin olarak Vatikan ve Dresden yazmalarından farklılık gösterir. Gerek biçimsel yapısındaki gerekse muhtevasındaki farklılığı, bu yazmayı Dede Korkut Kitabı'nın bir nüshası olarak isimlendirmenin yanlış olacağını göstermektedir (Sertkaya 2019a). Salur Kazan ise diğer iki yazmada olduğundan çok daha ön plana çıkan ve metindeki bütün hikâyeleri kuşatan bir kahramandır.

Günbed yazmasının 38-39. sayfalarında ${ }^{1}$ yer alan ve Kazan'ın ad kazandı̆̆ını anlatan soylama, Kazan'ın destansı kişiliğini oluşturan temel çizgileri vermekte, bir anlamda Kazan'ın hikâyesini özetlemektedir. "Ben" diliyle ilerleyen bu soylama, hem Dresden yazmasının 11. hikâyesinde Kazan'ın kâfirlere karşı kopuz çalıp söylediği şiirlerle, hem de Topkapı Oğuznâmesi'nin 3. sayfasındaki Kazan konulu bölümle paralel anlatılar içermektedir. Bu anlatımların bir karşıllı̆ı da Şecere-i Terâkime'deki manzum parçalardadır. Bu dört metindeki ortak bir anlatı, "taş yuvarlanması" hadisesidir. Bu olay, Kazan'ı tarif eden önemli bir hikâyedir.

Bulut teşbihi ile başlayan soylamada vak'a aktarımına geçiş de bu hikâyeyle olmuştur. Metnin bütününe nazaran şiirsel dilden kısmen uzaklaşılan bu aktarım, metnin bir "boy" olarak değerlendirilmesinin de zeminini oluşturur. Nitekim AzMun bu metni bir boy olarak değerlendirmiştir (2019: 8; 2020: 17). Olaya, olayın mekânına dair ayrıntılar bu anlatının tarihselliğine yorulabilecek önemli

\footnotetext{
$\mathrm{Bu}$ çalışmada Günbed yazması için Ekici'nin verdiği sayfa numaraları takip edilmiştir. Buna göre SHAHGoLi et. al.'ın yapmış olduğu numaralandırma bir adım geriden hesaplanabilir. AzMuN'un numaralandırmasını bulmak için ise bu numaradaki sayıyı 2 ile çarpıp çıkan sonuçtan a-b dizilişine göre $a$ varsa $2, b$ varsa 1 eksiltmek gerekir. EKici, SHAHGoLi et al. ve AzmuN'un çalışmasında söz konusu sayfa sırasıyla $20 a, 19 b$ ve 38 şeklindedir.
} 


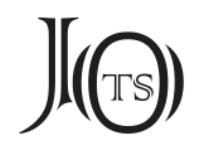

konulardandır. Metnin bağlamında ise Kazan karakterinde destan kahramanlarının akılcılıkla ve içkiyle ilişkisine dair düşündürücü bilgiler ediniriz.

Yuvarlanan taşı tutmanın, konusu Kazan olan soylamalarda ve şiirlerde hep anılan bir hadise olması, ejderhayı yenme hikâyesinde olduğu gibi bu konuda da bir hikâyenin ilerde ortaya çıkacağını düşündürmektedir. Şimdilik yapabileceğimiz bu hadiseye dair ipuçlarını toplayıp bir eldeki malzemelerden bir değerlendirme yapmaktır.

Günbed yazmasındaki yuvarlanan taş epizotunun aydınlatılması konusunda elimizdeki bu metinle kıyaslayacağımız dört metin bulunmaktadır:

1. Şecere-i Terâkime'deki Kazan konulu şiir

2. Dresden yazmasındaki övünmedim redifli soylama

3. Topkapı Oğuznâmesi'ndeki Kazan'ın kendi erliklerini andığı soylama

4. Altay Türklerinden derlenen hikâyeler

Saydığımız metinlerden ilk üçü, doğrudan bir karşılaştırma yapabilmemize imkân tanır. Ancak Altay Türklerinden derlenen rivayetler, hem karşı taraftan bir bakış olması ve farklı bir zemin içermesi, hem de doğrudan Salur Kazan etrafında bir anlatı olmaması sebebiyle daha dolaylı bir karşılaştırma unsurudur. Bu yüzden bu son rivayete ayrı olarak yer verilecektir.

Bu anlatı, Kazan şahsında bir kahramanın taşıması gereken temel özellikler hususunda önemli şeyler söylemektedir. Bu yüzden çalışmamızın önemli bir amacı, yuvarlanan taş anlatısının taşıdığı mesajları değerlendirmek, anlatının çözümlemesini yapmaktır. Bu çözümleme hem Salur Kazan'ı hem de Dede Korkut hikâyelerinin zeminini daha iyi tanımada bir katkı olur kanaatindeyiz.

\section{Yuvarlanan Taş Anlatısının Kıyaslamalı Okunuşu ve Değerlendirilmesi}

Günbed yazmasının 17. soylamasında yer alan ve yuvarlanan taş adını verdiğimiz anlatıyla ilgili kısım şu şekildedir:

Aḳalarum götürmişdüm, Ala Çaḳuy Çolpa Dag̉ınuy dibine gitmişdüm,

Buyurmışdum, ala sāybān çatılmışdı, 


\section{J(৫)}

La'lî çaḳır süzülmişdi, körpe ḳuzı çevrülmişdi,

Aḳalarumla içeridüm.

Kayadan bir ḳara daş ayrıldı geldi,

Saḳdaki bégler saḳa ḳaçdı, soldaki bégler sola ḳaçdı,

Sak elümden sol elüme piyāleni tepretmedüm.

Karılarumı ḳarşı vérüb ḳara daşı sahlayan Ġazan idüm. (25b/7)

Metne göre Salur Kazan, ağalarını (beylerini) alıp Ala Çak'un Çolpa dagı (?) diye bir dağın eteklerine gitmiş, orada bir sofra kurdurmuştur. Bu sırada kayalıklardan bir taş yuvarlanmış, beyler sağa sola kaçışırken Kazan yuvarlanan taşı tutmuştur. Bu metinle birebir örtüşmese de bu metne paralel anlatım içeren elimizdeki metinler şu şekildedir:

\begin{tabular}{||l||l||}
\hline \hline Şecere-i Terâkime (84) & Kazgurt tagdın üngür taşnı yugarlatdı \\
& Salur Kazan utru barıp karbab tutdı. \\
& lt Beçene körüb anı isi kitdi \\
& Alplar bigler kören bar mu Kazan kibi ? \\
\hline \hline Dresden yazması (140b/12) & Yüksek yüksek kara dagdan taş yuvarlansa \\
& Kaba ökçem uylugum karşu tutan Kazan er idüm. \\
\hline \hline Topkap1 Oğuznâmesi (3/58) & Karaçıg'un Cılban tagından kâfir taş uçursa \\
& Kaba oylugun dutan, ben Kazan-idüm. \\
\hline
\end{tabular}

Tablo I: Eşmetinler

Elimizdeki bu yeni anlatım, diğer anlatımlarda olmayan bir başlangıç durumu içermektedir. Bu başlangıç, olaya yeni ayrıntılar katar. Şahıs kadrosu ağalar ve Kazan Bey'den ibarettir. Mekân ise Ala Çak'in Çolpa dagı'nın dibidir. Zamana dair bir işaret yoktur, ancak güzel bir yaz günü olduğu tahmin edilebilir. Anlatımdaki bu unsurların her birisinin değerlendirilmesi yapılmalıdır. Kazan'ın yuvarlanan taşı tutma hadisesi için, bütün metinlerden ortak bir kalıba ulaşmak zor görünmektedir. Bu konudaki ilk müşkül olayın ortamında, daha sonra mekânında, üçüncü olarak da taşın nasıl bir hareketle etkisiz hale getirildiğinde 


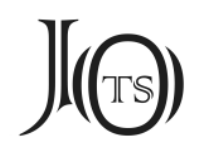

yatar. Taşın ne şekilde ve niye yuvarlandığı konusu metinlerde farklılık gösteren bir konudur.

\section{I.1. Olayın Başlangıç Durumu: İçki Sofrası Tablosu}

Soylamada yuvarlanan taşla ilgili anlatı Akalarum getürmişdüm cümlesiyle, bir içki sofrası bahsiyle başlamaktadır. Metnin önceki kısmı istiare ve telmih içerirken burada gerçek bir sahne tarifi ve vak'a aktarımı vardır.

Bir içki meclisinin hadiselere başlangıç noktası olarak belirmesi, Dede Korkut hikâyelerinin tekrarlanan bir yönüdür. Toy veya meclisi tanımlayan içki sofrası tablosu, anlatılacak hikâye için girizgâh olmaktadır. Bu sofralar, hikâyelerin kahramanları olan yönetim kadrolarının bir araya geldiği, bu yönüyle protokol anlamı da taşıyan durumlardır. Dresden yazmasındaki on iki hikâyeden yedisi bu türden bir içki sofrası ile, özelde toy ile başlar ve bu toylardan üçü de Salur Kazan'a aittir. Yemeli içmeli, ala çadırlı meclisler, içki sofraları eski Türk yaşayışının önemli bir olgusudur ve övgü sebebidir. Genel olarak Dede Korkut metinlerinde içkinin yerilişinin Deli Dumrul'un Azrail'den af dilemesinde olduğu gibi birkaç örnekle sınırlı olduğunu söylemek mümkündür.

İçki sofralarının övgüyle anılışını iki açıdan değerlendirmek mümkündür: Birincisi, bu sofraların beylerin ikramını, zenginliğini gösteren bir beylik nişanesi olmasıdır. Yapılan ziyafetin en değerli iki nesnesi şarap ve ettir. Et, av etinden dadlu kebab ve çevrülmiş körpe kuzı olarak, şarap ise al şarap, çakır veya la'lî çakır adıyla bu metinlerde yer bulur. Şarap anlamındaki la'li çakır deyimi, değerli bir taş olan la'l'in kırmızı renginden dolayı, bir istiare yoluyla al şaraba isim olmuştur. Diğer Dede Korkut metinlerinde ağırlıklı olarak bahsedilen içki al şarap iken Günbed yazmasında şarap anlamında hep bu kelime kullanılmıştır. Şarabın süzülmesi ve kuzu kebabı yapılması ise bu meclisi tamamlar. ${ }^{2}$ Şarabın dibindeki tortunun alınması için süzülmesi, içki meclislerinde yapılagelen bir işlemdir.

2 İçki sofralarının dağ yamacında, çeşme veya akarsu yanında kurulup kuzu kebabı yapılmasına dair klasik şiirde olduğu gibi türkülerde de örnekler bulunmaktadır: Soğuksu başındakuzu kebabı/İner düz ovaya çeker şarabı. 


\section{$J(\Theta)$}

Şecere-i Terâkime'de meclislerde içkinin bol olmasının Oğuz Han'dan kalma bir gelenek olduğu anlatılmaktadır. Günbed yazmasında da neye yarar neye yarar redifli soylamada içki kurma'nın çok daha ayrıntılı metni vardır (5b/9-6a/7).

İçki sofralarının ikinci yönü, kahramanın gücüne ve korkusuzluğuna bir delil olarak sunulmasıdır. İçmek, düşman karşısında bir gevşekliğe sebep olmamakta, kahraman yine korkusuzca gelen saldırıyı veya tehlikeyi püskürtmektedir. Ele aldığımız anlatıda bu husus ağırlık taşır

Günbed yazmasında buna benzer bir tabloyu, Alagez'in ağzında Şaraphâne düzünde yüz bin kâfirin kırıldığı ve Kars kalesinin alındığı savaş öncesinde görmekteyiz. Burada yine beyleriyle içerken Kazan'a düşman tarafından bir haberci gelmiş, “Gazan ne içersin?” diyerek Kazan'ı uyarmış, Kazan ise bu uyarıyı dikkate almamıştır. Topkapı Oğuznâmesi'nde ve Dresden yazmasında da paralel metnini gördüğümüz bu anlatıda Kazan ayrıca On min yagı geldigüni eşidende kol getürüb otag içinde oyuna girdim (24b/12-13) bile demektedir. ${ }^{3}$ Böylece içki içmekle birlikte oyun oynamak da, düşmanı küçümseme ve güç gösterme hareketi olarak vurgulanmaktadır. Dahası, Kazan'ın bu sofradan sonra kalkıp abdest alıp namaz kıldığı da anlatılmıştır. Bu dikkat çekici ayrıntı, kahramanın sarhoş olmama kudretinde görüldüğüne bir işaret olarak da alınabilir. Böylece içki, içmesini bilmek gibi bir anlama bürünerek kahramanın hüner hanesine yazılmaktadır.

Bu metinde içki hem bir başlangıç durumu, hem de olayın ayrıntısı olarak yer almıştır. Kayalıklardan kopup üzerlerine doğru yuvarlanan taş karşısında Kazan sakindir ve elinden piyalesini bile düşürmemiştir. Tehlikeden korkmama, mizahî bir mübalağa ile, piyalenin teprenmemesi ifadesiyle anlatılmıştır. Anlatılan “taş yakalama” hünerinde Kazan'ın içmekten geri durmaması, yiğitliğine dair ç1karılacak en önemli bir hissedir. Kazan halk tabiriyle içmesini bilmektedir.

\section{Ala Sâybân}

Ala sâybân (veya sâyebân) içki meclisinin merkez mekânıdır. Meclis bu gölgeliğin altında, yere döşenen halıça'lar üzerine kurulur. Ala saybân deyimindeki

3 Bu söyleyişi Topkapı Oğuznâmesi'ndeki metin ile karşılaştıran UçAR, eşmetinde geçen On biy eren gördüğümde oyunum démedüm cümlesindeki daha önce okunuşunda ihtilaf olan oyunum kelimesinin 'dans' anlamında alınması gerektiğini söyler (2020: 219-220). 


\section{$J(\Theta)$}

ala kelimesini, birçok Dede Korkut araştırmacısı 'yüksek' anlamıyla yorumlamaktadır. Rengi değişse de sâybânlar için yükseklik vurgusu yapılagelir. Sâybân (önceki metinlerde sâyvân), altında beylerin bağdaş kurup oturduğu, üzeri atlas veya deriden örtülerle kapatılmış büyük bir gölgeliktir. Dresden yazmasında atlas ilen yapılanda gök sayvanlı (104a/13), yeni yazmada ise ejdehâ derisinden düzelmiş sâybânı dikdi (30b/1) şeklindeki ifadelerle farklı sayebân tarifleri karşımıza çıkar.

Ala sâybân, protokolü temsil eden ve hüner gösterme yeri olarak meydanı oluşturan bir unsurdur. Kahramanın gücünü gösterme yeri olan meydan, herhangi bir yerde bulunan boş bir alan değildir (Çetinkaya 2013: 86). Genellikle bir protokol önüdür. Sportif gösterilere, yarışlara sahne olan toyların en merkezinde de ala sâybân bulunmaktadır.

Olaylar genellikle bir meydanda, yani protokolün önünde gerçekleşmekte, kahramanlar burada imtihandan geçmekte ve burada takdir edilmektedir. Dede Korkut Kitabinda olayların başlangıcı, bir toplanma merkezi olan ala sâybân'da gerçekleşir. Toplumsal durumların ortaya çıkışında ve kararların alınışında, toplumun da onaylanmış, kabul edilmiş merkezi sayılan ala sâybân, bir hükümet etme yeri olmaktadır.

\section{I.2. Şahıs Kadrosu}

Kazan kendisiyle birlikte akalar'dan bahsetmektedir. Akalarum götürmişdüm ve buyurmuşdum sözleri, Kazan Han'ın bir bey olarak yüksek bir yerde konumlandığını göstermektedir. Metnin devamında Kazan vekillik rütbesi de alacaktır ancak anlatımın kronolojik bir akış gösterdiğini söyleyemeyiz.

Sağdaki beyler ve soldaki beyler ile İç Oğuz'un ve Dış Oğuz'un beyleri kast edilmiş olmalıdır. Kazan'ın oğlu Uruz'la olan hikâyesinde de sağ tarafında kardeşi Kara Göne, sol tarafında Aruz oturmaktadır. Aynı zamanda bir protokole işaret eden bu isimlendirişi Kars kalesinin fethini anlatan sahnede şu şekilde görmekteyiz: İç Oguzun beglerini sakdan saldum. Dış Oguzun beglerini soldan buyurdum $(26 b / 3)$. 


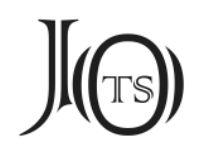

Sağın ve solun protokoldeki değeri konusunda farklı gelenekler mevcuttur ama Dede Korkut Kitabı'nda sağ tarafın daha üstün olduğu görülmektedir (Pehlivan 2014: 205). Kazan'in hâkim konumda olduğu meclislerde Kazan'ın sağ yanında kardeşi Kara Göne, sol yanında ise Dış Oğuz beyi olan dayısı Aruz Bey bulunmaktadır.

Soylamanın devamında İç Oğuz'un beylerinden ve Dış Oğuz'un akalarından söz edilmiştir. Aka kelimesinin akrabalık anlamına atfen İç Oğuz için (Kazan İç Oğuz’a mensuptur) tercih edildiği de düşünülebilse de metinde ayrım yapılmadan hem İç Oğuz ve hem Dış Oğuz için bey tabirinin kullanıldığı yerler mevcuttur. Bey gibi toplumun önde gelen kimselerine işaret eden aga kelimesi, 'yaşlanmak' ve 'büyümek' arasında kurulan ilginin önemli bir hatırasıdır (Kaydarov-Orazov 2010: 58) Biz sağdaki ve soldaki konumlanışlarından hareketle protokolü İç ve Dış Oğuz'un beyleri olarak düşünebiliriz.

Bu bey veya ağaların kimliğine dair Dede Korkut metinlerinde bilgiler çoktur. Derli toplu bir isim listesi için ise Bahrü'l- Ensâb Oğuznâmesi'ne bakılabilir. Bu eserde Der-beyan-ı Evsaf-ı Bayındır Khan başlığıyla Anlar din mezheb bilmez-idi ammâ, Hakk'a ikrârları var-idi denilerek Oğuz taifesi şu şekilde tanıtılmaktadır:

\footnotetext{
Aralarında Taş-Oğuz İç-Oğuz Begleri anğılur idi. İç-Oğuz Beglerine Kazan-Khan, Budak Bek, Yagân Bek, Şamşoldın Bek, Bayarak Bek, Kara Konak Bek derler-idi. Taş-Oğuz beglerine Oruz Koca, Dondar Bek, (Bogduz) Aman Bek, Avuşar Beg, Dokar Bek, Rustam Bek bunlara Taş-Oğuz Begleri derler-idi. (Kırzıoğlu 2000: 20-21)
}

Oğuz beylerinin yuvarlanan taş anlatısındaki başlıca rolü, bir kıyaslama ve şahitlik unsuru olmalarıdır. Kazan hünerini onların önünde ve onları geride bırakarak gerçekleştirir.

Meclisin bir dağ eteğinde düzenlenmiş olması, bu meclisin bir av eğlencesi olduğunu düşündürmektedir. Kadından ve halk unsurlarından yalıtılmış, tamamen yüksek statülü erkeklere ait bir mekân söz konusudur. Meclis kurulduğu halde kâfir güzellerden bahsedilmemiştir.

Dresden yazmasındaki ve Topkapı Oğuznâmesi'ndeki paralel anlatıda beylere temas yoktur. Kâfir taş uçursa ifadesi, bir taraf olarak düşmanı da olaya dâhil etmiştir. Fakat Şecere-i Terâkime'deki paralel metinde şahıs kadrosu çok daha geniş 


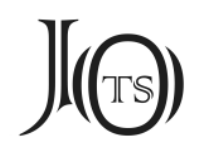

olmalıdır. Becene veya Becene halkı da olayın şahidi olmuş, büyük şaşkınlık yaşamıştır. İt Becene halkı ile Salurlar arasındaki düşmanlık dikkate alınırsa hadisenin bir suikast teşebbüsü olduğu da böylece ortaya çıkar. Ayrıca bu metinde geçen Kazgurt adı, aşağıda da ele alacağımız üzere, mekân adı olarak değerlendirilmiş olsa da taşı yuvarlayan kişi olarak olayda bir taraf olmaya uygun görünür. Hadisenin suikast olduğu anlamı şecere-i Terâkime metni ile Topkapı Oğuznâmesi'nde açıktır.

\section{I.3. Mekân}

Doğa, Dede Korkut hikâyelerinde mekân sembolizmi için önemli bir kaynaktır (Çetinkaya 2015: 151). Hem olayların fizikî zemini, tarihsel bir işareti, hem de bir değer yükleme konusu olarak mekânlar, Dede Korkut metinlerinin detaylı incelenmesi gereken yönlerindendir. Destan anlatılarında doğa, insanın ayrılmaz bir parçası gibidir. Bu aynı zamanda mitolojik anlatıların geniş bir mekân alg1sıyla şekillenmesine de zemin oluşturur. Kahramanlar gibi kahramanın içinde bulunduğu çevre de büyüktür. Yine de burada belli bir çevrenin işaretlenmesi, metnin buraya kadar olan kısmındaki mitolojik mekân algısından farklıdır ve nettir.

Dresden yazmasındaki anlatımda mekân yüksek yüksek kara dağ şeklinde verilmişken bu metinde, somut olarak belirtilmiş, sınırları çizilmiş bir mekân vardır: Ala Çakuy (veya Alaçak'un) Çolpa dagı. Fakat kayalıklarından kara taşın yuvarlandığı, dibinde ala sâybân kurulan bu dağ nerededir?

\section{Ala Çak'un (veya Alaçak'un) Çolpa Dagı}

Topkapı Oğuznâmesi'nde aynı olayın mekânı olarak Karaçıg'un Cılban Tagı adı verilmiştir. Görüleceği üzere iki metinde dağ adı çok az değişmiştir: Alaçak'un Çolpa - Karaçıg'un Calban. Topkapı Oğuznâmesi'ndeki Cılban veya Calban şeklindeki okunuş, bu metinde Çolpa olarak karşımıza çıkmıştır. Çolpa dagı kısmını SHAHGOLi et al. çülpe olarak okumuş ancak farklı da okunabilir diye şerh düşmüştür. Her iki isim için böyle bir yer adının tespit edilemediğini de eklemiştir (2019: 217).

Çolpa, sözlüklerde 'ayağı sakat olan' mecazen de 'beceriksiz, acemi' anlamlarında geçen bir kelimedir. Aslında kelimenin çulpa okunuşu da mümkündür ve 


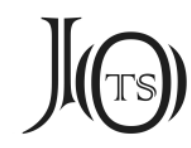

bu kelime de Azerî Türkçesinde 'kent tavuğu, piliç' anlamıyla kullanılmaktadır. Topkapı Oğuznâmesi'ndeki cılban veya calban okunuşunu 'Çolpan' olarak düşünmek belki mümkündür. 'Çobanyıldızı' anlamına gelen Çolpan, aynı zamanda mitolojide tanrının baş çobanı olan ayı temsil eder. Yıldızların başı olarak görülen Çolpan, çobanların da piri ve hamisidir (Bayat 2006: 60, 105). Bu ilişki ister istemez akla Kazan'ın Karaçuk Çoban'ını getirecektir. Nitekim Karaçık adının Karaçuk Çoban'la ilgisi olabileceği araştırmacılarca hep düşünülmüştür. Karaçuk Çoban ile ilgili hikâyede ise olayın mekânı Kapılı Dervend ve Kapılı Kara Dervend adıyla geçmektedir. ${ }^{5}$ Bu sebeple KıRzıoĞLu bu dağ için Oğuz illerinin kuzey sınırlarına işaret etmektedir (2000: 41).

KIRZıŏ̆LU, ayrıca Oğuznâme metinlerini dikkate alarak hazırladığı Oğuz Elleri Haritası'nda Karaçuk'ung Calban tagi'na Alburz bölgesinde, Güre Kâfir Elleri'nin batısında konumlanan bir dağ olarak yer vermektedir. ${ }^{6}$ Bu haritalar için önemli bir kaynak olan Kaşgârlı Mahmud'un Karaçuk için verdiği bilgi 'Oğuz kentlerinden biri olan el-Farab kentinin adı' olduğundan ibarettir (Ercilasun-Akkoyunlu 2015: 213). Fakat sözlüğün başındaki ünlü haritasında Oğuz yurdunu Karacuk sıradağları olarak göstermiştir. Oğuzların bu dağlarda yaşadığını kabul eden SÜMER'e göre bu dağlar Sirderya boylarındaki bugünkü Karatav dağlarıdır (1959: 100). EYÜBOĞLU da eserinin sonuna aldığı haritada, Sir Derya nehri boyunca Karadağlar, Karaçuk ve Kazıgurt adlarını sıralamıştır (2019: 815).

Karaçık kelimesi Salur Kazan'la ilgili övgülerde Karaçuk'un kaplanı şeklinde bir kalıp ifadede de görülmektedir. Salur Kazan'ın Karaçuk'un kaplanı olarak övül-

4 KIRZIoĞLU, Calban Tagi'nın Çelebiyan'dan gelmiş olacağını düşünmüştür: Karacuk-Çoban'ın yerini ve Calban (belki de, Çelebilü/Çelebiyan) adlı Türk oymağı ile alâkalı bulunan Çalaban/Çalban tagı'nı, Tiflis kuzeyinde ve Daryal geçidine yakın yerdeki Kara-Kalkan yaylakları üzerinde aramak, daha doğru olsa gerektir (2000: 80). Fakat yeni metindeki Çolpa okunuşu, bu yorumun uzağına düşmektedir.

5 Kara Dervend, Bay Büreoğlu Bamsı Beyrek hikâyesinde bezirgânların saldırıya uğradığı yer olarak geçmektedir. ERDEM, Kara Dervend'in Türkmenistan'ın başkenti Aşgabat yakınlarındaki Gavers reyonunda (Enev'de) bir dağ geçidi olduğu ve bu ismin aynı zamanda 'geçmesi zor olan yer' anlamında kullanıldığı bilgisini aktarmıştır (2005: 173).

6 KIRZıoĞLU, Hakkâri'de (3150 m.) Calban dağı olduğu bilgisini vermektedir (2000: 91). Bunlara ilave olarak culban adı, baharat kültürümüzün bir unsuru olarak karşımıza çıkmaktadır. Ayrıca Anadolu'da calba, çalba, şalba gibi isimlerle anılan bir dağ çiçeği türü bulunmaktadır. 


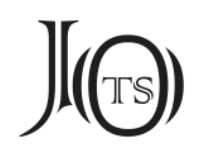

mesi, hakkında anlatılan yuvarlanan taş hikâyesiyle ilgili gibidir. Fakat Karacuk'un kaplanı övgüsüne benzer bir övgü, Topkapı Oğuznâmesinde "Osmanoğlu" hakkında "Kara dagun kaplanı" şeklinde kullanılmıştır (2/9). ${ }^{7}$ Bu kullanış hem kelimenin deyimleşmiş bir cins adı olabileceğini, hem de Salur Kazan'a has bir bağlantıya işaret etmediğini ihtimal dâhilinde tutar.

Karaçıg'un Calban tagı için yapılan yorumlar yeni metindeki Alaçak kelimesine cevap olmamıştır. Bu sebeple yeni metindeki bu kelimeler araştırmacılar tarafından çokça tartışılacaktır. Her iki metindeki ifadeleri değerlendirerek basit düzeyde birkaç fikir yürütebiliriz:

Her iki metinde de dağ, bir isme nispet ediliyor gibidir. Karaçuk veya Karaçık, aynı şekilde Alaçak adı, burada bir bölgeyi veya önemli bir şahsı işaretliyor gibidir. Nitekim Azmun'un Günbed yazmasından İngilizceye yaptığı çevirilerde Çolpa Dağı'nı 'Ala Çak' bölgesi içinde değerlendirdiği görülmektedir: "I had taken my elders and gone to the lower slopes of Mount Cholpa in Ala Čaq" (2020: 26).

Cılban ve Çulpa aynı kelimenin görünümleri gibidir. Karaçık kelimesinin aksine Alaçak'taki /k/ ünsüzünün yumuşamadan tamlayan ekine bağlanması, çak'ın ayrı bir kelime olmasını akla getirebilir. Çak'ın farklı anlamları içinde en bilineni ‘zaman' olup bu anlamiyla elimizdeki metinde de birkaç yerde geçer. Kelimenin ayrıca ‘dişi köpek' anlamı (Öztürk 2005: 240) ${ }^{8}$ ve 'bölmek' anlamı ile ilişkili gözüken 'işaretlenip belirlenen toprak parçası, bölünen pay' anlamı bulunmaktadır. (Kyýasowa et al. 2016: 210). ${ }^{9}$ Fakat bu ihtimaller aydınlatıcı değildir.

Bir ihtimal, Ala Çakuy ile Çolpa dagı kelimelerini, zincirleme olmayan bir isim tamlamasının iki ayrı tamlayanı olarak düşünmektir: Ala Çak’n dibi ve Çolpa dagı'nın dibi. Bu durumda iki ayrı yer adı, aynı bölgeyi işaretliyor demek olacaktır.

7 Metin, Ulu Sultan budağı, Gazi Hân'un torunu, kara bulut örgüni, Karadağ’ụ kaplanı, Kara şahin yavrusu, Saru Saz'un kaplanı şeklinde ilerlemektedir. Bu övgüler Kazan Han ve Bayındır Han için kullanılan övgü sözleriyle paraleldir.

8 ÖzTÜRK'ün Karadeniz Ansiklopedik Sözlüğü’nde Rize Güneysu'da Çak isminde bir irmak olduğu bilgisi vardir.

9 Türkmen Dilinin İzahlı Sözlüğü'nde bu bilgi şu şekilde verilmiştir: Ýer paýlanyşygynda, ýap gazylanda bölünip berlen ýer; ara belligi, bölünen paý. Men gazy gazýan, ertir menin çägimi alyşmaga kömekleş A. Durdyýew. (H Kyýasowa et al. 2016: 210) 


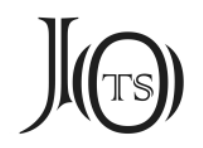

Aslında AZMUN (2019: 52) ve SERTKAYA'nın (2019: 639) bu iki ifadeyi metinde virgüllerle ayırarak vermesi, bu ihtimali düşündürür. Elbette paralel ifadeler olarak Karaçıg'un Calban tagı için de aynısını düşünmek lazım olur: Karaçıg'un tagı ve Calban tagı.

Bu bölge adlandırışına dair bir ihtimal de, ifadede eksik bir kelime olmas1dır. Böyle bir değerlendirmede Ala Çak, Çolpa Dağı'nın dibindeki özel bir yere işaret edecektir: Ala Çak'ın [oraya], Çolpa Dağının dibine gitmiştim.

Dede Korkut Kitabı'nın eksiltili ve devrik yapılı cümleleri arasında bu ifade, belki makul sayılabilir. Aynı eksiltili oluşu paralel metne uyarladığımızda, yuvarlanan taş Karaçıg'un [oradan], Calban Dağı'ndan yuvarlanmış olacaktır. Calban Çolpa benzerliğini de kattığımızda iki metin arasında belli bir uyumun oluşması önemli bir bulgudur. Karaçıg dağın yukarısını, Alaçak ise aşağısında bir bölgeyi işaret ediyor olmalıdır. Bu durumda Alaçak kelimesinin 'alçak' anlamı (Kaçalin 2006: 166, 262) akla gelse de alaçık metinde çok daha anlamlı duracaktır.

\section{AlaçakSözü Acaba Alaçık Kelimesi Olabilir Mi?}

Bu ilgiyi kurmamı için sebep, alaçık kelimesinin ağızlarda alaçak şeklinde de geçiyor olmasıdır (Karabulut-Kazanlar 2018: 410). Kaşgârlı Mahmud, sözlügüne bu kelimeyi Er alaçulandı örneğiyle, alaçu olarak almıştır. ${ }^{10}$ Alaçu '(alaçık), üzeri dal ve hasırla örtülmüş kulübe, çardak' anlamındadır (Clauson 1972: 128b; Parlatır et al. 1998: 71b). ${ }^{11}$ Dolayısıyla Alaçak’n [oraya] gitmek, mesire için önceden belirlenmiş olan belli bir mekâna gitmeyi ifade edecektir. 0 zaman bu bölge,

10 ERCilasun-AKKoyUnLu, bu kelimeyi sözlükte 'geniş çadır' (2015: 547), ÖzTÜRK, 'büyük çadır' olarak çevirmiştir (2016: 47). SADIQLI, alaçu'nun 'geçici olarak kullanılan yazlık evi' olduğunu söylemektedir: "Yayda havalar isti keçdiyina göro, Türklor yaylaq vaxtı çadır və ya keçədən bina, coma, alaçıq qururdular. Qışlaqda iso daha çox qazma damlar tikirdilar, çünki qış nisbatan soyuq olurdu. Yaylaq evlori müvaqqati olurdu, qlşlaq evlari isa daimi yaşamaq üçün nazarda tutulurdu." (2016: 169).

11 Alaçuk kelimesi tartışmalı bir kelimedir (Karabulut-Kazanlar 2018). Moğolcada alaga, Rusçada ise laçuğa şeklinde bulunan kelimenin farklı lehçelerdeki ve Türkiye ağızlarındaki görünümlerine de yer veren Karabulut-Kazanlar 2018'de kelimenin kökenine ve açıklamasına dair bir dizi görüş sıralanmıştır. Kelimenin bir kelime ve küçültme ekinden oluştuğu yaygın bir kanaattir. Söz konusu makalenin yazarları da kelimenin oluşu ile ilgili "ala(yarım)+evcik, ala(yarım)+ocak, ala+çıg (saz otundan yapılan kumaş veya bölme), alaca+höyük (tepe), Halaç” gibi tespit ve önerilerde bulunmaktadır. Bu makaleden alıntılanan şu bilgi de dağ adının çobanla ilişkili olduğunu düşündürür: “Anadolu'nun bazı bölgelerinde de 


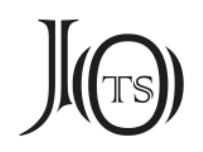

Kazan Bey için belli bir konaklama yeri anlamına gelmelidir. Ayrıca alaçık'ın 'çoban kulübesi' anlamı da yine Karaçuk Çoban'ı hatırlatacak bir bilgidir. Karaçuk Çoban'ın adının da Dresden yazmasında birkaç yerde Karaca Çoban olarak geçmesi gibi bu kelime de bazı ağızlarda alaça şeklinde görülmektedir.

Alaçık'ın 'çadır, çoban evi, çardak, kulübe' gibi anlamları yanında 'oba, güneşsiz yer' gibi anlamları da bulunmaktadır. Derleme Sözlüğ̈̈’nde kelimenin 'ormanların ortasındaki boşluk' anlamına yer verilmiştir: Ol yer ki güneş az dokuna ve hiç dokunmiya ve alacuk. (Karabulut-Kazanlar 2018'den, Deşişî Mehmet Efendi, Eh Tuhfetü's-Seniyye XVI. 238/1).

Alaçak kelimesinin 'güneş almayan' anlamı, Salur Kazan'ın sâyeban kurduğu düzlük olarak da uygun görünmektedir. Bu anlam doğrultusunda, adı anılan mekânı, 'gölgelikli, kuytu bir bölgede yer alan, çobanların konakladığı' bir mekân olarak düşünebiliriz. Bu bölge, Çulpa veya Cılban/Calban Dağı'nın eteğinde yer alır ve alçakta bulunduğu için de kayalıklardan buraya taş yuvarlanması olasıdır. Karaçık için bu durumda yapabileceğimiz tek yorum, bu ismin dağın yukarı kısımlarını ifade ediyor olmasıdır. İki metinde farklı mekân adlarının verilmesi rivayetlerin çeşitliliğine yorulmayacaksa ki bu hep mümkündür, ancak bu şekilde anlaşılabilir.

Bunun dışında iki metnin isimlerini ayniyle kabul etmek için, ya KAÇALiN'in ala=kara değerlendirişini ${ }^{12}$, yahut da bu dağların karşılıklı iki dağ olduğunu kabul etmek gerekecektir. Birincisinde Alaçak zaten Karaçak demek olur. İkincisinde ise taşın kuzeydeki Karaçık’ın Cilban (veya Çolpan) Dağı'ndan kopup, güneydeki Alaçak'ın Çolpa (veya Çulpa) Dağı'nın dibinde beyleriyle oturmakta olan Salur Kazan'a doğru yuvarlandığını düşünmek gerekecektir.

bu kelime çobanların köyden uzak bölgelerde geçici olarak ikamet ettikleri ya da uzakta bulunan tarlalarda çalışanların eve dönüs yolunda zaman kaybetmemesi için kurdukları hasırdan, tahtadan veya çalliklardan hızlıca inşa edilmiş kulübe ve barınaklar için kullanılmaktadır" (Johansen 2013: 197).

12 KAçALin'e göre Arapça a'lâ kelimesiyle ilişkili olan ala kelimesi, 'yüksek' anlamındadır ve kara'nın yerine kullanılabilmektedir (2006: 254). KAÇALiN, ayrıca kara kelimesinin Arapça 'parlak, yüksek, gösterişli' anlamındaki garrâ' dan dönüşmüş olabileceğini ileri sürmüştür (2006: 215). Bu yoruma göre 'dağın yüksek olması', hem ala hem kara şeklinde adlandırılması için bir sebeptir. 


\section{J(৫)}

Elbette destan metinlerini Köprülü̈nün deyimiyle birer "parça” kabul etmek en doğrusudur (1980: 41-45). Açı bir paralellikten dolayı ben bu iki muhtelif parçadaki mekân adlandırışını, yukarı - aşağı şeklinde bir değerlendirişle birleştirmeyi tercih ediyorum. Bu iki metinde mekânın adının bu şekilde net bir ifade ile anılması, bu mekânın belli bir coğrafî bölgeye karşılık geldiğini düşünmek için bir sebeptir.

Dresden yazmasındaki paralel metinde geçen Yüksek yüksek kara dağdan daş yuvarlansa ifadesi, makro ölçekli bir değerlendiriş olarak hadiseyi mitolojik bir boyuta taşımaktadır. Oysa Günbed yazmasındaki kayadan bir taş ayrıldı ifadesi, gerçekçi bir tariftir. Yuvarlanan taş, dağdan değil kayadan ayrılmıştır. İçkili meclisin kurulduğu yer sarp kayalıklar karşısında veya dibinde olsa gerektir. Şüphesiz bu hikâye de Kazan'ın yaşadığı yerlerin coğrafi özellikleri hakkında bir fikir vermektedir.

Kara dağun kaplanı ile Karacuğun kaplanı ifadelerinin eş değerde kullanılmalarına bakılacak olursa Dresden ve Topkapı Oğuznâmesi'ndeki ifadeler bizi kesin olarak yüksek bir dağa götürecektir. Kara dag 'yüksek dağ' anlamında alınabilecek bir ifadedir. Birçok destanda yeryüzünün zirvesi olan bir kara dağdan bahsedildiği görülmektedir

\section{Kazgurt Dag}

Şecere-i Terâkime'deki Kazan Han'ı öven şiirde ise Kazgurt adı geçmektedir:

Kazgurt tagdın ünür taşnı yugarlatdı

Salur Kazan utru barıp karbap tutdı

İt Beçene körüp anı issi kitdi

Alpler bégler kören bar mu Kazan kibi

SERTKAYA, bu mısraları şu şekilde çevirmiştir:

Kazgurt Dağı'ndan Öngür taşı yuvarlattı. Salur Kazan karşı çıkarak kavrayıp tuttu. Pecene halkı onu görüp aklı başından gitti. Alpler, beyler! Kazan gibisini göreniniz var mı? (2019: 641). 


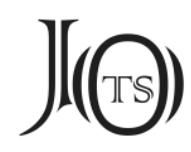

Şecere-i Terâkime'deki manzum parçaları değerlendirdiği makalesinde KARGI, Kazgurt tagdın üñoür taşnı yugarlatdı dizesini Kazgurt dă̆(ı)dan mağara(nın önünde duran) taşı yuvarlattı biçiminde çevirmenin uygun olduğunu söylemektedir (1991: 86). Bu makalede KonoNov'un da bu mısrayı Kazgurt dağından geçen boğazda (duran) taşları yuvarlamışlardı şeklinde çevirdiği aktarılmıştır (Kargı 1991'den Kononov 1958).

Bu mısralardaki Kazgurt ifadesi, Oğuz ilinin kıble yönündeki bir dağ olarak yorumlanmaktadır (Sümer 1959: 100, 391). Şecere-i Terâkime'deki bu dağ adı ile Topkapı Oğuznâmesi'ndeki dağ adının farklılığı, Kazgurt dağını Karacuk sıradağlarından bir dağ olarak kabul etmekle çözülmüştür. Bu şekilde her iki metin de birbirini destekleyicidir. Fakat bu mısralardaki Kazgurt adı, kişi adı olarak alınırsa hikâye değişecektir. Nitekim ERGiN’in (1978: 84) Kazgurt dağdan aşağıya taşı yuvarlattı şeklindeki okuyuşunda Kazgurt bir kişi adı olarak alınmıştır. Ayrıca mısranın başında bir özne bulunması bu dörtlükteki genel uyumla örtüşmektedir. Yugarlat- fiilinin öznesi diğer çevirilerde ya göz ardı edilmiş yahut da Salur Kazan olarak düşünülmüştür. KARGI'nın yorumunda Salur Kazan'ın hem taşı yuvarlayan hem de karşı gidip taşı tutan olduğu anlaşılır. Aslında bu anlamlandırış, bu metni paralel anlatımlardan bağımsız olarak yorumlamanın zorluğunu ortaya koyar. Kanaatimce bu mısralar elimizdeki diğer metinlerle bir parça aydınlanmıştır.

Şecere-i Terâkime'de bu olayı arka planda incelediğimizde Kazgurt'un bir kişi adı olma ihtimali güç kazanır. Esere göre Becene ve Kazgurt, Oğuz'un bir mirasta bir çadır etrafında birleştirilen torunlarıdır ve Becene boyu ile Salur boyu arasında ise beş altı nesildir süregelen bir düşmanlık bulunmaktadır. Oğuz'un, annesi cariye olan bir torunu olan Kazgurt, Bayındır ve Becene'ye tabi kılınmıştır. Eserde Becene ile Salurlar arasında devam eden savaşta üstün gelen Becenelerin Salur Kazan'ın annesi Çaçakl'yı esir aldığı da hikâye edilmektedir. Haddi aşmış olan Becene halkı için Salurlar, It Becene demektedir. ${ }^{13}$ Buradaki Kazgurt eğer kişi adı ise farklı zamanda yaşamış, Becene halkından biri olmalıdır. Buna göre Kazgurt adlı kişi Salur Kazan'a suikast tertiplemiş, dağdan taş yuvarlayarak Kazan'ı hedef al-

13 Salur Kazan'la ilgili Türkmenistan rivayetlerinde İt Becene adlandııışını hatırlatır şekilde İtemen, İtemcek gibi düşman adları geçmektedir. 


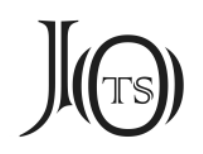

mış, Kazan ise taşı karşılayıp çekmiş olacaktır. Topkapı Oğuznâmesi ve Günbed yazmaları ile kıyasladığımızda Şecere-i Terâkime'deki Kazgurt'un dağ değil bir şahsı işaretlediğini düşünmek mantıklıdır. Buna bir de Kazgurt Dağ şeklindeki bir tamlamanın sıkıntılı olacağını ekleyebiliriz.

SÜMER, Dede Korkut hikâyelerini Oğuzlar ile Peçenekler arasındaki tarihî mücadelelerin destanî hâtıraları olarak kabul etmek gerektiğini söylemektedir (1999: 392). Bu durumda taş yuvarlama hadisesinin Peçeneklerle Salurlar arasında bir olay olması uzak bir ihtimal değildir. Peçeneklerin Oğuzların yaşadığı coğrafyadaki varlıkları, IX. yüzyıldan itibaren Karadeniz'in kuzeyinde görülmeleri ve Anadolu'da da etkili olmaları (Demir 2016: 772), Dede Korkut hikâyeleriyle ilgisi hakkında fikir vermektedir. Boylar arası çekişmeler, iktidar mücadeleleri tarihsel bir kayit olarak efsanelere, destanlara konu olmakta, milletlerin eski hatıraları edebî bir esere dönüşmektedir.

\section{I.4. Olay}

Kayalıktan kopan taş, gölgelikte oturmakta olan beylere doğru yuvarlanmaya başlamış, beyler telaş içinde sağa sola kaçışırken Kazan yerinden kımıldamamış, hatta kadeh tutan elini bile değişmemiştir. Bu etkili aksiyon sahnesi, Kazan'ın taşı karular'ının arasına alarak tutmasıyla sonlanmıştır. Bu durumda Kazan taşı ne şekilde tutmuş olur?

Metinde Kazan'ın taşı tutmasını tarif için karılarumu karşı verüb ifadesi kullanılmıştır. Karı kelimesine sözlüklerde verilen anlamların çeşitliliği burada tarif edilen hareketi anlamamızı zorlaştırır. Zira karı hem 'önkol' hem 'üst kol' bölgesini ifade ettiği söylenebilen, tartışmalı bir kelimedir. Farklı Türk lehçelerinde kar, gar, karı, karu, garı gibi şekillerde geçen bu kelimenin TENişEV Moğolca gar kelimesinden, CLAUSON ise kar- fiilinden geldiğini ve karış kelimesiyle ilgili olduğunu düşünmektedir (1972: 644b-645a). Bu yüzden TUFAR, Türkçedeki organ adlarını incelediği çalışmasında, kelimenin 'kolun omuz kısmı, omuz ile dirsek arasında olan kısım ve önkol' anlamlarının temel anlamları olduğunu söylemiş̧ir (2010). Koyun, keçi gibi hayvanların dizi ile toynağı arasındaki kısım anlamına da gelen karu, ayrıca yarım kulaca denk gelen bir ölçü birimidir. (Tufar 2010: 202) 


\section{J(৫)}

Kaşgârl, sözlüğünde bu kelimeyi Arapça żirâu'l-yed ile karşılamış, ayrıca kelimenin 'kumaş ölçmekte kullanılan ölçü' anlamını da yine żirâ' kelimesiyle vermiştir. Zirâ' kelimesi 'dirsekten orta parmak ucuna kadar olan uzunluk ölçüsü' olarak kullanılmaktadır (Çağbayır 2007: 5489a-b). Böylece karı kelimesi, 'kolun dirsek ile parmak ucu arasındaki kısmı' olarak anlaşılır (Ercilasun-Akkoyunlu 2016: 686).

Hal böyleyken bu kelimeyi metnimizin bu kısminda Azmun 'bacak', Ekici ise 'sırt' şeklinde çevirmiştir (2019: 81; 2019: 191). AzMUN, kelimeyi çalışmasının sözlükçesine 'bacağın dizden ayağa kadar olan bölümü' anlamıyla almış, ayrıca 'Türkmencede kolun uzunluğunu gösteren, Farsçadaki arşın gibi bir uzunluk ölçüsü olduğu' bilgisini de vermiştir. Exici'nin bu kelimeye metnin başka yerlerinde 'hayvanın arka ayakları, pazu, kürek kemiğ' anlamlarını verdiği, sözlükçeye ise 'pazu ve kürek kemiği' anlamlarıyla aldığı görülmektedir. AzMUN ise kelimeyi çalışmasının sözlükçesine 'bacağın dizden ayağa kadar olan bölümü’ anlamıyla almış, ayrıca "Türkmencede kolun uzunluğunu gösteren, Farsçadaki arşın gibi bir uzunluk ölçüsü olduğu" bilgisini de vermiştir.

Dede Korkut metinlerinde karısundan ag ellerin baglamak, yayı karusuna geçirmek deyimleriyle karşımıza çok kez çıkmış olan bu kelime, yeni yazmada, kurdun karlar üstüne yatmasını tarif eden karularını döşeyip uyumak şeklindeki deyimde geçmektedir. Karusundan ellerin bağlanması deyiminde 'bilekle dirsek arasındaki kısım' kastedilmiş olabilirken, yayın karuya geçirilmesinde kelimenin 'kol ve sırt' anlamı daha uygun düşmektedir. Bizim burada ele aldığımız taş tutma hadisesinde hareketin 'ön kol' bölgesiyle yapılmış olması, bilekten aşağısının, ellerin olaydan hiç etkilenmemesi demek olacaktır. Bu da şüphesiz artistik bir mübalağa olur. Kazan Bey'in imkân sınırlarını zorlayan taş tutma hareketi, karı kelimesini anlamlandırmada belki de bu sebeple farklı tercihlere yol açmıştır. Bu kelimeyi çözme çabamız da metindeki bu görkemli hareketi doğru tespit etme kaygısındandır.

Azmun'a göre Salur Kazan, elinde kadeh (ki bağdaş kurmuş da olmalıdır) yuvarlanan taşı bacaklarıyla yakalamıştır. Bu yorumlayış elbette Dresden yazması ve Topkapı Oğuznâmesi'nde yazmasındaki 'uyluklarıyla' yakalamak şeklindeki anlatımla uyumludur. EKici ise, Kazan'ın taşı ‘sırtıyla’ tuttuğunu yazmıştır. Kazan’ın 


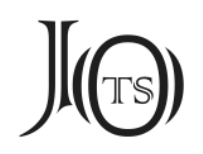

önden gelen taşa 'sırtıyla' hamle yapması ilgisiz bir hareket olarak görülebilir ve piyalenin teprenmemesine yapılan mizahî vurguyu anlamsız kılabilir.

Fakat taş ne taraftan gelmiştir? Eğer taş Kazan'in dibinde oturmakta olduğu dağdan, arka taraftan gelmişse Kazan'ın taşı, metindeki ifadeye uygun bir şekilde hiç istifini bozmadan sırtıyla karşılaması da gösterişli bir hareket olarak düşünülebilir. O zaman, Kazan bu yuvarlanan taşın tam kendi sırtına doğru geldiğini de bilmiş olmalıdır. Taşı karularının (kollarının arka kısmı ile omurga kemiğinin) arasına alması ise taşın 'saklanması' tablosunu artistik bir şekilde tamamlayacaktır. Kazan, bu külfetsiz ve sessiz hareketiyle yuvarlanan taşı etkisiz hale getirmiş ve kadehini içmeye devam etmiş olacaktır. Yuvarlanan taşa sırtını bile dönmeyerek yaptığı bu kahramanlık, belki de Kazan'ın eski adı olarak belirttiği Deli Dönmez adını da hatırlatabilir.

Taş karşıdan geliyorsa Kazan, bağdaş kurmuş haliyle taşı ancak ön kollarıyla tutabilir ve iki kolunun kavuşmasıyla saklayabilir. Karı kelimesine önkol anlamı vereceğimiz böyle bir durumda kadehin teprenmemesi yine mizahî mübalağaya elverişlidir.

Hadisenin Dresden yazması ve Topkapı Oğuznâmesi'ndeki anlatımında taş tutmada bacakların kullanıldığı açıktır:

Kaba oylugun dutan ben Kazan-idüm (140b/12)

Kaba ökçem, uylugum karşu tutan Kazan er idüm (3/58)

Topkapı Oğuznâmesi'nde uylukla birlikte ökçe'nin de anılması, olayı sportif bir gösteriye dönüştüren, dikkate değer bir ayrıntıdır.

Şecere-i Terâkime' de ise olay karbab tutdı 'kavrayıp tuttu' şeklinde tarif edilmiştir. 'Elle yakalamak, ele geçirmek, kapmak, tutmak, sımsıkı tutmak' anlamlarina gelen (Karg1 1991: 86-87) bu tarifte yakalama hareketi el ile sinırlıdır ve bu yüzden Salur Kazan'ın elinde kadeh olması detayına elverişli değildir. Fakat Günbed yazmasındaki anlatıma yine de en yakın tutuş tarifi bu olsa gerektir. Böylece yeni yazmayla birlikte yuvarlanan taşı tutmak, biri el, biri kol biri de bacakla gerçekleşen üç değişik pozisyonda Salur Kazan'ın yiğitliğini sergileyen bir hikâye olmaktadır. 


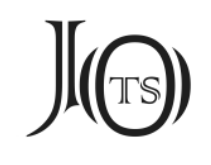

Metnimizde dağdan yuvarlanan taş kara sıfatıyla verilmiştir. Kara taş destan metinlerinin dilinde alışıldık bir kelimedir. ${ }^{14}$ Azmun, bu kısmı 'siyah bir kaya' diye çevirmiş olsa da kara, taşın ağırlığını, kuvvetini de ifade ediyor olabilir. Siyah taş ile ilgili ilginç bir mütalaa, ONAY'ın eserindeki penbe-i mînâ maddesinde bakılabilir (1999: 363). ${ }^{15}$

Piyalenin teprenmemesi şeklindeki mizahî mübalağa, yeni yazmanın yuvarlanan taş anlatısına eklediği önemli bir ayrıntıdır. Zaten içki sofrası ve piyale bahsi de diğer anlatılarda yoktur.

\section{Altay Türklerinden Derlenen Hikâye İle Karşıllaştırma}

Salur Kazan ve yuvarlanan taş ile ilgili bir başka hikâye Altay Türkleri arasında anlatılmaktadır. Ancak bu hikâyede yuvarlanan kaya parçasını bacakla yahut kucakla değil, "başıyla karşılama ve yerine gönderme" şeklinde bir motif vardir.

RADLOFF tarafından Sibirya'daki Altay Türkleri arasından derlenen hikâyenin kahramanı Ak-Kübek'tir. Salur Kazan bu destanda yardımcı ve rakip karakter pozisyondadır. Destanda Ak- Kübek'in mücadele ettiği asıl karakter Kidan (veya Kodan) Han'dır. Kidan Han Ak-Kübek'i yenmek için evvela oğlu Manguş'u yollamıştır ve destanın önemli bir kısmı bu mücadeleye dairdir. Manguş’un ölümü üzerine intikam için bu kez Kidan Han Salur Kazan'ı göndermiştir. Elbette burada Salur Kazan'ın bir kağanın emrindeki güçlü bir komutan olması, savaşmak için sahaya gönderilmesi önemli bir benzerliktir.

Efsaneye göre Salur Kazan savaşmak için Ak-Kübek'in evine gider. Kimliğini gizlemek için kendisini Ak-Kübek'in aşçısı olarak tanıtan Ak-Kübek, Kazan'la bir hüner yarışına girer. Okun ucunu ateşte kızdırıp ağza koymak, bir ırmağın içinde durup altı gün sonra irmak iyice donunca buzu parçalayarak çıkmak şeklindeki değişik hünerler arasında ikinci hüner taşlarla ilgilidir:

14 KAÇALiN, karataş kelimesine ‘taş kömürü’ anlamını vermiştir (2006: 268). Kara taş, Kara Göne’nin övgüsünde karşımıza çıkar: Acıgı dutanda kara taşı kül eyleyen Kara Göne (Dresden 31b/10).

15 Burada bir beyit hakkındaki türlü yorumları nakleden ONAY sonunda, "Delinin biri kuyuya taş atmış kırk akıllı çıkaramamış" atalarsözünü hatırlamamak kabil değildir", der. 


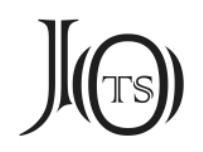

Ak-Kübek dağdan yuvarlanan kayaları, başı ile vurarak yeniden, dağın doruğuna atar. Salur Kazan da aynı şeyleri yapar. (Bu mücadelede berabere kalırlar) (Ögel 2014: 42, Tavkul 2008: 599-618).

FALEV, buradaki Salır Kazan adının, Kuzey ve Güney Türkleri arasındaki karş1lıkl ilişkiyi gösterdiğini söylemektedir (Urmançeyev 2016: 199). ÖGEL'in de dikkat çektiği bu anlatıyı POTANiN ve TAVKUL, diğer Nart destanlarıyla da karşılaştırmıştır.

Kafkas kültürünün önemli unsurlarından biri olan Nart destanları ile Dede Korkut ve Oğuznâme metinleri arasındaki ortak ilişkileri ele alan TAVKUL'un aktardığına göre Kübek ile Salur Kazan arasındaki mücadele ayniyle Karaçay- Malkar ve Oset Nart destanlarında başka kahramanlar arasında da geçmektedir. ${ }^{16} \mathrm{Bu}$ anlatılarda asıl kahraman bir zekâ sembolüdür ve kötü karakteri zekâsı ile alt ederek öldürür. Yine bu destanlarla paralel bir şekilde Altay Türklerinin anlat1sinda da Salur Kazan asıl kahramana değil, "olumsuz, yok edilmesi gereken, olağanüstü güçlere sahip” bir karaktere karşıllk gelmektedir. Salur Kazan, Ak-Kübek arasındaki mücadelede Salur Kazan'ın karşı taraftan görünüşünün söz konusu olması açısından bu anlatılar sosyo-psikolojik bir değer taşır. Dikkate değer bir durum, bu Altay anlatısında kahramanlığın zekâ yanında güç de gerektirmiş olmasıdır. Nart destanlarında ise rakip tamamen oyuna getirilerek yenilmektedir.

Salur Kazan'ın 'güçlü bir yiğit' olarak karşı tarafta anılışı, Koblandı Batır Destanı'nda da görülmektedir. Bu destanda Kazan'dan Kızılbastıı elinen / Kazan degen er şıktı/Jön bilmegen şer şıktı "Kızılbaşülkesinden Kazan adlı er çıktı. Beklenmeyen dert çıktı" (Kuanışbayeva 2002: 133) şeklinde, olumsuz olarak söz edilmekte, fa-

16 Nart destanlarında yer alan "suyun içine girme ve donan suyun içinden çıkamama" motifi Dede Korkut'un Türkmenistan rivayetlerinde de yer etmiştir. Salur Kazan ile ilgili bu rivayetlerden biri 1947'de, diğeri 1966'da derlenmiştir. Bunlardan birinde rakip İtemcek, diğerinde İtemen'dir (Bu isimlerin AkKübek'le ilgisi düşünülmektedir). İlk rivayette İtemcek büyüyle suyu dondurur fakat Salur Kazan'a yenilir. Diğer rivayette ise Salur Kazan, İtemen'in 'eğer sen güçlü isen' şeklindeki kandırmasıyla suya girer ve donan suyun içinden çıamaz. İtemen böylece başını kesip onu öldürür (Ayrıntılı bilgi için bk. Erdem 1998). Muhtemelen aynı zemin üzerine oluşan bir hikâye birbirine zıt bakış açılarıyla farklı şekiller almıştır. Burada dikkat çeken bir husus, menkıbelerde, "kaynar suyla dolu bir kazana girip kırk gün içinde kalmak" şeklinde motiflere rastlamamızdır. Kazan adından dolayı bu ilişki de dikkat çekicidir (Haznedaroğlu 2020). 
kat kahramanın güçlülüğü de (Kazan sındı batırın ‘Kazan gibi bir yiğidin’) vurgulanmaktadır. Bu birbirinden farklı destanların Kazan kişiliklerinin aynı veya ona yakın bir tarihî kişiliğge karşılık gelip gelmeyeceği tartışılabilir. Türk’ten 'kötü ve düşman bir kardeş’ olarak bahseden, Türk soyunu kötüleyen Şan Kızı Destanı'nda da bir Gazan vardır ve bu Gazan ‘Hun neslinin yenileyicisi’ olarak övülür, Türk’le savaşan neslin öncülerinden olur.

Ak-Kübek anlatısı için ÖGEL, "Dede Korkut ve Oğuz destanları içinde böyle geri ve ilkel sahneler yoktur” yorumunu yapmıştır (2016: 42). Bu yorum URMANÇAYEV'in görüşlerine çok zıttır. Anlatının şiirsel diline, sanatsal derinliğine dikkat çeken URMANÇAYEV, Ak-Kübek'in düşmanıyla uzun uzun konuşmasını hasımların mukadder çatışmalarının psikolojik hazırlığı olarak değerlendirir ve metni çok derinlikli bulur (2016: 190).

Nart destanlarındaki demir vurgusu ve "demirci Nart kahramanı" motifi, elimizdeki metnin karşı taraftan karakterinin "Ala Demür Kâfir Han” olması dolayısıyla ayrıca dikkat çekmelidir. Salur Kazan ve yuvarlanan kaya parçalarıyla ilgili bir hikâyenin birbirinden farklı anlatılara yansıdığı görülmektedir.

Bu farklı anlatılardan aşağıdaki tabloyu elde etmekteyiz:

\begin{tabular}{|c|c|c|c|c|c|}
\hline Metin & $\begin{array}{l}\text { Dresden } \\
\text { Yazması }\end{array}$ & $\begin{array}{l}\text { Günbed } \\
\text { Yazması }\end{array}$ & $\begin{array}{l}\text { Şecere-i } \\
\text { Terâkime }\end{array}$ & $\begin{array}{c}\text { Topkap1 } \\
\text { Oğuznâmesi }\end{array}$ & $\begin{array}{l}\text { Altay Türkle- } \\
\text { rinden Der- } \\
\text { lenen Hikâye }\end{array}$ \\
\hline Mekân & $\begin{array}{l}\text { Yüksek yüksek } \\
\text { kara dağdan } \\
\text { (veya Kara- } \\
\text { dağdan?) }\end{array}$ & $\begin{array}{l}\text { Ala Çakuy Çolpa } \\
\text { Daginuy dibine } \\
\text { gitmişdüm. }\end{array}$ & $\begin{array}{c}\text { Dağdın } \\
\text { (veya) } \\
\text { Kazgurt Dağdın }\end{array}$ & $\begin{array}{l}\text { Karacigun Cilban } \\
\text { Tağından }\end{array}$ & $?$ \\
\hline Olay & $\begin{array}{c}\text { Taş yuvar- } \\
\text { lansa... }\end{array}$ & $\begin{array}{c}\text { Kayadan bir } \\
\text { kara daş ayrildı } \\
\text { geldi }\end{array}$ & $\begin{array}{l}\text { Üygür taşı yu- } \\
\text { garlatdı }\end{array}$ & Kâfir taş uçursa & $\begin{array}{c}\text { (Dağdan kaya } \\
\text { parçaları yu- } \\
\text { varlanır) }\end{array}$ \\
\hline $\begin{array}{c}\text { Taşı } \\
\text { Karşılama } \\
\text { Şekli }\end{array}$ & $\begin{array}{c}\text { Kaba ökçem uy- } \\
\text { luğum karşı tu- } \\
\text { tan... } \\
\text { (uyluklarıyla) }\end{array}$ & $\begin{array}{l}\text { Karularumu } \\
\text { karşı verüb kara } \\
\text { taşı sahlayan... } \\
\text { (kol, pazu gü- } \\
\text { cüyle) }\end{array}$ & $\begin{array}{c}\text { Utru barip } \\
\text { karbap tutdı } \\
\text { (kucaklayarak) }\end{array}$ & $\begin{array}{c}\text { Gaba uylugum } \\
\text { dutan } \\
\text { (uyluklariyla) }\end{array}$ & $\begin{array}{l}\text { (Başıyla taşı } \\
\text { karşılayıp da- } \\
\text { ğın doruğuna } \\
\text { yollama) }\end{array}$ \\
\hline $\begin{array}{c}\text { Olayın Şahit- } \\
\text { leri }\end{array}$ & & $\begin{array}{c}\text { Sakdaki beyler } \\
\text { saka kaçdl, sol- } \\
\text { daki beyler sola } \\
\text { kaçdı }\end{array}$ & $\begin{array}{c}\text { İt Becene anı gö- } \\
\text { rüb issi gitti }\end{array}$ & & \\
\hline
\end{tabular}




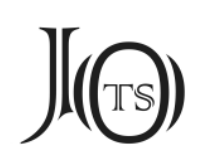

\begin{tabular}{|c|c|c|c|c|c|}
\hline $\begin{array}{l}\text { Kahraman- } \\
\text { Lığın Mahi- } \\
\text { yeti }\end{array}$ & $\begin{array}{l}\text { (Tesadüfen geli- } \\
\text { şen bir olaya } \\
\text { aninda mukave- } \\
\text { met) }\end{array}$ & $\begin{array}{l}\text { (Tesadüfen geli- } \\
\text { şen bir olaya } \\
\text { anında mukave- } \\
\text { met) }\end{array}$ & $\begin{array}{l}\text { (Saldırıya karşı- } \\
\text { lık mukavemet) }\end{array}$ & $\begin{array}{c}\text { (Saldırıya karşıllk } \\
\text { mukavemet) }\end{array}$ & $\begin{array}{c}\text { (Hüner yarış- } \\
\text { tırma) }\end{array}$ \\
\hline
\end{tabular}

Tablo II: "Yuvarlanan taş" ile ilgili anlatımlar

Birçok Dede Korkut araştırmacısının hemfikir olduğu üzere, Salur Kazan'ın elimizdeki destanlarda bulunmayan fakat derin izleri destanlarda yer etmiş hikâyeleri vardır ve bunlardan biri de bu taş yuvarlanması hadisesidir. Ejderha hikâyesi gibi bu hikâyenin de metninin ortaya çıkması birçok soruya çözüm olacaktır.

\section{Yuvarlanan Taş Anlatısının Temel Mesajları}

Salur Kazan'ın yuvarlanan taş anlatısının bir destanî hikâye olarak karşımıza çıkması, taşıdığı anlamlar üzerine düşündürmelidir. Her şeyden önce bu metin, Kazan'ın kahramanlıklarını kendi dilinden aktardığı bir övünme metnidir. Dolayısıyla Kazan, erkek olmakla ilgili en güçlü idealleri yansıtmaktadır.

Soylamaya bütün halinde baktığımızda "ad kazanmak, yüksek bir mevkie yükselmek, yüksek bir değeri temsil eden bir kadına sahip olmak" en temel erkeklik idealleri olarak takdim edilmektedir. Soylamanın başında bulut olmak teşbihi ve ejderha hikâyesine telmih ile kahramanın gazap etme gücü en baştan vurgulanmıştır. Güçlü, korkusuz ve yenilmez olmak, bütün soylamanın olduğu gibi bütün destansı anlatıların da en temel mesajıdır. Dikkatli bir bakışta akıl dışıllğıın da bu mesaja eşlik ettiği görülecektir. Fizikî gücün övgüsü, bir muhakeme yeteneği olarak aklı kahramanlar için çoğu zaman gereksiz bir unsur kılmakta ve güçsüzlerin ve nâmert olarak tanımlanan düşmanın tasarrufuna bırakmaktadır. Bu anlatının paralel metinlerinde de bu husus ön plandadır. Düşmanı yenmenin, tasavvuftaki ilâhî aşkın aklı yenmesi düşüncesine karşıllı olarak düşünülebilecek bir anlama büründüğünü söylemek mümkündür.

Yuvarlanan taş anlatısında güçlü olmaya dair vurguyu pekiştiren birkaç ayrıntı olduğu görülmektedir. Bunlardan ilki kahramanın tedbirsizliği, ikincisi ise bu tedbirsizlikle birleşen içki içmeye düşkünlügüdür. İçki sofraları donattırma 


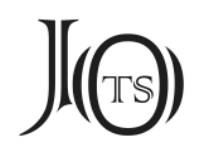

kahramanın zenginliğidir. Tehlikeye talip olma kahramanlığın var oluşsal anlamıla bütünleşmektedir. Gücün gösterişli ve estetik bir formda sunulması ise, etkiyi arttıran bir husus olarak anılmalıdır.

\section{Telaşsızlığa (ve Tedbirsizliğe) Övgü}

Metnin dilinde tedbire karşı ince bir alay, sağdaki beyler sağa kaçdı, soldaki beyler sola kaçdı sözüyle ifade bulur. Telaşa düşenlerin gülünç halleri bu şekilde ballandırılarak anlatılmıştır. Kazan, vuk'u bulacak olayı adeta gülerek seyreder ve bir vaziyet almaz. Bu durum Kazan'ın geldiği söylenen düşmana karşı hiçe saymak, azdur demek şeklindeki küçümseyişini hatırlatır. Kazan on min yagı geldigüni eşidende kol getürüb otag içinde oyuna giren (24b/12) bir kahramandır. Yaklaşan tehlikeye karşı sükûneti korumak, panik yapmamak, burada kahramanın çok esaslı bir yönüdür. Bu telaşsızlık aynı zamanda tedbire tenezzül etmeme anlamı taşır.

Çok defa bu tedbirsizliğin bir gelenek olarak sunulduğu görülmektedir. Kazan Bey'in tutsak düştüğü boy bu hususta anılmalıdır. Bu hikâyede Kazan, kâfir sınırlarında olduğunu bilmesine rağmen bir Oğuz beyi âdeti olarak küçücek ölüme, yani 7 gün sürebilen derin bir uykuya dalmıştır. Kazan uyurken gelen düşman 25 beyi şehit eder, Kazan'ı da bağlayıp götürür. Nihayet arabanın gıcırtısından uyanan Kazan'ın yaptığı ise elin eline vurup kas kas gülmek olur (Dresden 138b). Kazan'ın umursamazlığına uç misaller veren bu hikâye, düşman aklıyla alay etme konusunda da diğer hikâyelerden oldukça farklıdır. Tedbir almanın zayıf bir karaktere işaret ettiği, yuvarlanan taş anlatısında temsil bulan önemli bir husustur.

Eklemek gerekir ki Dede Korkut hikâyelerinde tedbirli davranmak, mantık yürütmek daha çok bir kadın davranışı olarak ortaya çıkmaktadır. Selcen Hatun, Dirse Han'ın hatunu ve Segrek'in nişanlısı, akılcılık timsali sayılabilecek örneklerdendir. Hesaplı ve tedbirli davranma alp igidlerin küçümsediği bir seçenektir, bu yüzden sağa sola kaçan beyler Kazan için alay konusu olmuştur. Kahramanın akılcı davranma yeteneği bazı sahnelerde toplumsal kabuller tarafından açıkça baskılanmaktadır. Dede Korkut Kitabı'nın deyim dağarcığındaki başına kahınıç yüzüne tohunç olma deyimi, kahraman üzerindeki toplumsal baskıyı ifade etmektedir (bk. Dresden 89b/4, 27a/72). Tedbirli davranmanın vurgulu bir şekilde, Bams1 


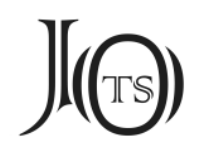

Beyrek boyunda, bir "deli"den kız istemeye giden Dede Korkut şahsiyetinde belirmesi düşündürücüdür. Burada Dede Korkut'un bir gazaya gider gibi hazırlanması, yedeğine at alması ve Oğuzlarla vedalaşması, kutlu bir kişinin bir deli karşısındaki çaresizliğini de gösteren esprili ayrıntılardır. Yuvarlanan taşı tutan Kazan'ın eski adı da Deli'dir ve bu isim tedbiri gereksiz bırakan bir güçlülüğün ifadesi olmaktadır.

\section{İçki Sofrası Kurmaya Övgü}

Yukarda da bahsedildiği için burada uzun bahsetmeyeceğiz. Fakat bol nimetli Salur Kazan'ın şahsında övülen çok önemli bir beylik nişanesi, içki kurmalar ve sofra çekmelerdir. Bir Dede Korkut deyişi olan, Ogul atadan görmeyince sofra çekmez (Dresden 3b/12) sözünün hikmeti, etli ve şaraplı beylik sofralarıyla karşımıza çıkmaktadır. Süzülmüş la'lî çakıra (şaraba) bazen av etinden dâdlu kebablar, bazen de çevrülmiş körpe kuzunun eşlik ettiği bu sofralar, devletin zenginliğine ve güçlülüğüne işaret olarak anılagelir, uzun uzadıya anlatılır, övülür. Şecere-i Terâkime'de de ziyafet sofralarının methinde Oğuz Han, baş örnektir. Allah'ın seçilmiş bir kulu şeklinde anlatılan oğuz Han'ın bir ziyafetinin içeriği şu şekilde sayılmıştır: Dokuz yüz bin koyun, dokuz bin sığır (veya at), bunların derisinden yapılan doksan dokuz havuzun dokuzunu dolduracak kadar şarap ve doksan havuz dolusu da kımız (Ergin 1978: 41).

Günbed yazmasında Salur Kazan gibi Kıyan [Selçuk] oğlu Deli Dündar da Semür Suyı üstünde içki kuran ve Kubadan kış güninde el üstünde yayıl elma meze ile gelen olarak, iki yerde benzer şekilde övülmüştür (13a/7, 26a/12). Bu övgü, içki yanında meze temin etmenin önemli bir yiğitlik olduğunu bize söyler.

\section{İçki İçmeye Övgü}

Salur Kazan, elinden şarabı bırakmamaktadır. Kahramanlık hanesine yüksek puan ekleyen bu özelliğini, Salur Kazan'ın içkiden etkilenmemesi olarak da anlamak mümkündür. Nitekim bu yazmadaki Kars Kalesi'nin Alınması hikâyesinde Kazan'ın içki sofrasından kalkıp abdest alıp namaz da kılabileceğini öğrenmekteyiz. Böylece Kazan, içki içtiği halde sarhoş olmama kudretinde bir kahraman olarak belirmektedir. Zaferin Allah'a sığınıp dua etmesi sayesinde olduğu anlamı 


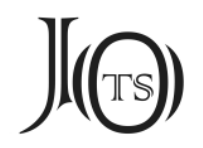

hikâyeye iliştirilmiş olsa da, içkinin Kazan'ın gücüne güç kattığı sezilmektedir ve içki içmekte İslamî bir sakınca görülmediği de açıktır.

Günbed yazmasında içkinin "içenine göre" anlam kazandığı şeklinde işaretler bulmaktayız:

Sömürüb sömürüb al şarâblar içmeğe mîzâç gerek (G.17a/7)

İçkisinde bed-mest igid bir gün olur yumrukda ölür (17b/6)

Salur Kazan'ın evinin yağmalandığı boy, Kazan'ın içkiyle (ve tedbirsizlikle) olumsuz anılışının tek örneğidir. Kâfir güzellerin kadeh sunduğu, görkemli bir içki sofrasıyla başlayan hikâyede içüb içüb alnına şarabuy itisi çıkan (Dresden 20a/9) Kazan, yanlış bir karar alır, ava çıkar ve evi için bir felakete sebep olur. Fakat bu acı hikâyenin sonunda yine aynı yere döner gibi oluruz: Kalın Oğuz beyleri doyum oldl. Yidi gün, yidi gice yime içme oldı (Dresden 34b/3).

Hâlbuki Kazan'ın ava çıkmaktan maksadı da sığın geyikyıkmak, otağa gelmek, yiyip içip hoş geçmek'tir. Yeme içme tutkusu hem sebep olarak, hem sonuçta karşımıza çıkmaktadır. Yuvarlanan taş anlatısında da zemin aynıdır. Bu yüzden çok yemek yemeyi de alpların özellikleri arasında saymak yerinde bir değerlendiriştir (Demirel 2015: 63). ${ }^{17}$

Bütün bunlardan çıarılacak hüküm, içki içmenin kişinin savaşma kabiliyetini köreltmediği ve düşmana firsat vermediği sürece kötü bir iş olarak görülmediği, hatta başlı başına bir hüner olduğudur. Böylece içme, halk tabiriyle 'içmesini bilmek' anlamına bürünerek özel bir biliş, bir irfan halini almaktadır. Kazan ele aldığımız anlatıda şaraptan anlayan ve bed-mest olmadan ondan istifade edebilen bir kahramandır.

17 Çok yemek, çok uyumak ve öfkesi kabarmak gibi, aslında tasavvufî gelenekte hiç iyi görülmeyen, çünkü özünde sınır tanımamaya dayanan davranışların destan kahramanları için bir şan olarak sunulması dikkat çekici bir ayrıntıdır. Kadın şahsında ise bu davranışların çok olumsuz görülüp kınanması, kültürü şekillendiren erkek egemen görüşün önemli bir yansıması olsa gerektir (solduran sop, dolduran top ve Boğazca Fatma örnekleri). 


\section{$J(\Theta)$}

\section{Tehlikeye Talip Olmaya Övgü}

Bunu bela aramak olarak da ifade edebiliriz. Kazan Bey'in taşın tehlikesinden, yana çekilerek kurtulması mümkündür, ama o yerinde kalarak beklemeyi tercih etmiştir. Çünkü bu tehlike, kahramanlığını ortaya koymak için bir fırsattır. Kahramanlar böyle firsatları özel olarak arar ve değerlendirirler. Dövüşmek, güç göstermek, destan dünyasında yapılacak tek iştir, Deli Dumrul bu yüzden köprü yaptırmıştır. Bunun gibi, Kazan'ın kâfir sınırında uykuya yatması, düşman elinde tutsak olduğu halde düşmana sövmesi, Kan Turalı'nın Trabzon'a kız istemeye gitmesi, hep bir belâ arayışıdır. Bütün destanlarda Kuday'dan düşman surağan / Jav körmese kuvarğan "Tanrı'dan düşman dileyen, düşman görmese kuruyan” (Kuanışbayeva 2002: 173) kahramanlar görmek mümkündür. Savaş1 neredeyse zorunlu hâle getiren ve sükûnet talebi olmayan bu bakış, destansı anlatılardaki güç gösterme kurgusu için elzemdir. Kahraman, intikam almak, suikasta uğramak, canavara rast gelmek gibi firsatlar yakalar. Görünüşe göre seçim kahramana aittir. Boğaç, boğa üzerine gelirken kaçanlardan olmadığı gibi Kazan da üzerine taş gelirken diğer beyler gibi kaçmaz.

Kazan'ın kahramanlık fırsatını nasıl bir sevinçle karşıladığına şu tablo da iyi bir örnektir: Ejderhanı görende Gazan'un tüm yüreği doldı taşdı, dünyâ âlem başına aydın oldı. (27b/13) Ejderhayı uyandırarak kahramanlığının pahasını arttıran Kazan'ın, elimizdeki metinde pahayı arttıran hareketi, elindeki piyaleyi tepretmemesidir.

\section{Şatafata Övgü}

Kazan yuvarlanan taşı oturduğu yerden tutmakla kalmaz, bu kara taşı sakladığını da söyler. Bu ifadeyle Kazan, beylerin, ağaların şaşkınlığına karşı alayı sürdürmektedir. Kazan'ın eski adının bu olayın mizahî yönünü daha anlaşılır kılacağı kanaatindeyiz. Salur Kazan'la ilgili birçok kahramanlık, özellikle 17. soylamada anılan hareketler, daima abartılı, şaşırtıcı hareketlerdir ve bu açıdan mizahî bir yön de içerirler. Nitekim yuvarlanan taş anlatısını takip eden kısımda Kazan, kimsenin boşken kaldıramadığı kara kazanı şarapla doldurup omzuna almasını ve (bilinmez ne şekilde) boşalttı̆̆ını da anlatmıştır. Kahramanlığın sıradan bir öykü olmaması bu abartıyı gerektirir. 


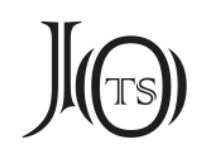

Şatafat arzusu, geleneğin çok önemli bir talebi olarak kahramanlara yön vermektedir. Bir bakıma en beklenmeyeni yapma kahramanlar için beklenilen bir şey olmaktadır. Bu şatafatın bir yönü de hadisenin estetik bir formda sunulmasıdır. Savaşmanın, çarpışmanın veya bir doğa gücünü alt etmenin sunuluşunda verilen görsel detaylar dikkat çekicidir ve bir şıklık içerirler.

\section{Sonuçlar ve Tartışmalar}

Günbed yazmasında anlatılan Kazan'ın kayalıklardan yuvarlanan taşı tutmasıyla ilgili anlatı, birçok açıdan bir destan kahramanı olarak Salur Kazan karakterini tanımlayan, kişiliğini çerçeveleyen bir hikâyedir. Bu anlatının dört metinde paralel anlatımlarının olması ve uzak yerdeki halkların destan anlatılarında bile bir yansıma bırakması, anlatılan hareketin kahramanla özdeşleştiğini düşündürmelidir.

Paralel anlatımlara baktı̆̆ımızda Günbed nüshasındaki anlatının en önemli ayrıntısının içki sofrası bahsi olduğunu görmekteyiz. Gerek olayın başlangıç zeminini oluşturması, gerekse Kazan Bey'in kahramanlığının en önemli ayrıntısı olarak sunulması, içkiyi ve içme durumunu bu anlatının en kritik noktası kılmaktadır. Kazan hem zengin bir bey sofrasının sahibi olarak, hem de içmekten geri durmayan bir kahraman olarak övülmektedir. İçki sofrası, Kazan'la ilgili pek çok anlatıda karşımıza çıkan temel bir şatafat unsurudur.

Yuvarlanan taş anlatısının okunması ve anlamlandırılması çalışmalarında en müşkül nokta, mekân adının ve anlatılan hareketin tam bir tespitinin yapılması noktasıdır. Mekân adı, daha önce Topkapı Oğuznâmesi'nde geçen Karaçık’uy Cilban Tagı şeklindeki okunuş üzerine düşündürmektedir. Bu okunuş hakkında vaktiyle yapılmış olan yorumlar Alaçak'un Çulpa Dagı okunuşunu aydınlatmaya yetmemektedir.

Çalışmamızda bu dağ adının anlamlandırılması üzerine bulabildiğimiz ihtimalleri arz etmeye çalıştık. İfadede Alaçak, bir bölgeyi, Çolpa Dagı ise o bölgedeki bir dağı işaretliyor görünmektedir. Alaçak ve Çolpa (?) Dagı isminin aynı bölge için kullanılması ihtimal dâhilindedir. Topkapı Oğuznâmesi'ndeki yer adı ile bu isim arasındaki uzlaşı, ya iki ismin aynı anlamda kabul edilmesi, ya karşılıklı iki dağ olarak değerlendirilmesi yahut da her iki metindeki ifadenin eksiltmeli olarak 


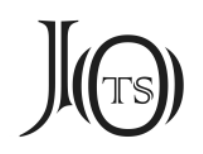

düşünülmesi ile sağlanabilmektedir. Bütün ihtimaller için Çolpa ile Cılban adlarını paralel değerlendirmek olasıdır. Eksiltmeli değerlendirişte Alaçak, Çolpa Dagı'nın eteklerinde, kayalıkların dibinde bulunan, Kazan'ın beyleriyle işret ettiği bir yer olmalıdır. Alaçık'ın 'yazlık mesken, çoban kulübesi' anlamı da, 'serin ve kuytu yer' anlamı da bu okuyuşa ve içki meclisinin mekânı olarak değerlendirilmeye uygundur. Karaçık ise kayalıkların bulunduğu, dağın yukarı kısmı olmalıdır. Taş bu kayalıklardan kopmuş ve Alaçak'ın olduğu yere yuvarlanmıştır.

Şecere-i Terâkime' deki paralel anlatımda bir dağ adı olarak değerlendirilmiş olan Kazgurt adı yeniden bir araştırma konusu olmalıdır. Şiirdeki uyum ve eserde olayın arka planına dair verilmiş olan bilgiler bu ismi mekân adı değil özne olarak değerlendirmeyi daha anlamlı kılmaktadır. Bu anlatımda yuvalanan taş olayı Kazan'a karşı bir suikast teşebbüsüdür. Hadisenin bir suikast olduğu anlamı Topkapı metninde de vardır.

Kazan'ın bu meclisteki ağaları, İç ve Dış Oğuz'un beyleridir. Kadınsız bir meclis olan bu ortam, bir kahramanın hüner gösterme yeri olan bir meydana karşllık gelmektedir.

Yuvarlanan taşı tutmak, elimizdeki metinde karılarumı karşı verüb sözüyle ifade edilmiştir. Karı kelimesinin hem ön kol, hem uyluk, bacak, hem de omuz, sırt gibi vücut bölgelerine işaret eden anlamları vardır. Bu yüzden metni günümüz Türkçesine aktaranlar 'bacak, sırt bölgesi' gibi farklı anlamları tercih etmişlerdir. Kazan'ın artistik bir gösteri anlamı taşıyan hareketini resmetmek için bu ihtimalleri değerlendirmeye çalıştık. Dresden yazması ve Topkapı Oğuznâmesi'nin bu olayda işaret ettiği karşılayış şekli bacak olmasına rağmen burada meclis dolayısıyla içki içmek söz konusu olduğu için kol ve omuz ihtimalleri daha makul olmaktadir.

Yuvarlanan taş anlatısı, muhtevası bakımından destani bir anlatının taşıyacağı temel mesajları sunabilen, oldukça karakteristik bir metindir. Bu özelliğinden dolayı ayrı olarak ele alınmayı gerektirmektedir.

Bu metinde Kazan şahsında bir kahramanının taşıması gereken özellikler olarak telaşsızlık ve tedbirsizlik, içki içmek (içkisinde bed-mest olmamak), içki 


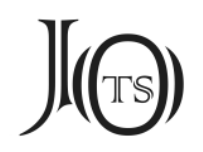

sofrası düzenlemek, tehlikeye talip olmak ve gösterişle insanları şaşırtmak meziyetleri öne çıkmaktadır. Bütün bu özellikler kahramanın güç gösterisini daha vurucu hale getiren değerlerdir. Güç göstermenin şartları akılcı bir ölçüyle belirlenmiş değildir. Bu yüzden kahraman, güçlü bir tabiat olayını ancak yiğitlikle bertaraf etmekte ve şan kazanmaktadır. Kahramanın akılcı davranmayı seçememesi, Dede Korkut Kitabi'nda başına kahınıç yüzüne tohunç olma deyimi ile ifade edilen normatif etkiden bağımsız düşünülmemelidir. Kazan'ın övünmesi ve diğer Oğuz beylerini küçümsemesi bu denklem içinde anlamlıdır. Yiğitliğin her şeyin üstesinden gelebildiği, ancak acizlerin telaşlanabileceği, bu anlatının en temel mesajı olarak okunmaktadır. Yuvarlanan taş anlatısı Kazan karakterini tanımlayan ve kahramanın ejderhayı öldürmesi kadar başat sayılacak bir kahramanlığı olarak Dede Korkut anlatıları içinde özel bir yere sahip olmalıdır.

\section{Kaynakça}

Azmun, Y. (2019). Dede Korkut'un Üçüncü Elyazması, Soylamalar ve İki Yeni Boy İle Türkmen Sahra Nüshası, Metin-Çeviri-Sözlük-Tıpkıbasım, İstanbul: Kutlu Yayınevi.

Azmun, Y. (2020). "The New Dädä Qorqut Tales from the Recently-Found Third Manuscript of the Book of Dädä Qorqut", Journal of Old Turkic Studies, 4/1:16-27.

BAYAT, F. (2015). Oğuz Destan Dünyası: Oğuznâmelerin Tarihî, Mitolojik Kökenleri ve Teşekkülü, İstanbul: Ötüken Neşriyat.

BozkURT, F. (2016). Divân-ü Lugat-it-Türk: Türk Dili Divanı, İstanbul: Salon Yayınları.

Clauson, S. G. (1972). An Etymological Dictionary of Pre-Thirteenth Century Turkish, Oxford: Oxford University Press.

ÇAĞBAYIR, Y. (2007). Orhun Yazıtlarından Günümüze Türkiye Türkçesinin Sözvarlı̆̆1, Ötüken Türkçe Sözlük V (tap-züz), İstanbul: Ötüken Neşriyat.

ÇETinKAYA, G. (2013). “Dede Korkut Hikâyeleri'nde Sembol Olarak Meydan”, Millî Folklor, 98: 73-86.

ÇEtinKaya, G. (2015). Dede Korkut Hikâyeleri'nde Semboller, Hacettepe Üniversitesi Sosyal Bilimler Enstitüsü, Ankara. (Yayımlanmamış Doktora Tezi) 


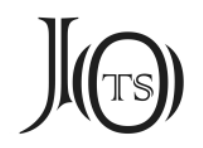

Demir, N. (2016) “Kazan İlçesine Bağlı Peçenek Mahallesi ve Tarihi Alt Yapısı”, IV. Kazan Uluslararası Halk Kültürü Sempozyumu Kitabı, Kazan Belediyesi Yayınları, Ankara: 763-772.

DemiR, N. (2020). Dede Korkut Destanı'nın Türkmenistan Boyları, İstanbul: Ötüken Yayınları.

DemiRel, H. (2015). Türk Destanlarının Ana Unsurları, İstanbul: Ötüken Neşriyat.

Ekici, M. (2019). Dede Korkut Kitabı, Türkistan/Türkmen Sahra Nüshası, Soylamalar ve 13. Boy, Salur Kazan'ın Yedi Başlı Ejderhayı Öldürmesi, İstanbul: Ötüken Neşriyat.

ERcilasun, A. B. \& , Z. AKKoYunLu (2014). Kâsşgarlı Mahmud: Dîvânu Lugâti't-Türk Giriş-Metin-Çeviri-Notlar-Dizin, Ankara: Türk Dil Kurumu Yayınları.

ERDEM, M. (1998). Dede Korkut Türkmenistan Varyantları, Ankara Üniversitesi, Sosyal Bilimler Enstitüsü, Ankara. (Yayımlanmamış Doktora Tezi)

ERGiN, M. (1978). Türklerin Soy Kütüğü Şecere-i Terâkime (Ebulgazi Bahadir Han), İstanbul: Tercüman Gazetesi.

EYÜBoĞLU, D. C. (2019). Korkut, İstanbul: Cinius Yayınları.

GÜLENSoY, T. (2007). Türkiye Türkçesindeki Türkçe Sözcüklerin Köken Bilgisi Sözlüğ̈̈ I-II, Ankara: Türk Dil Kurumu Yayınları.

HAzNEDARoĞLU, A.(2020). “Salur Kazan'ın Ad Kazanması Üzerine”, Dede Korkut Dergisi, 9/21: 163-185.

KaçALiN, M. (2006). Dedem Korkut’un Kazan Beğ Oğuznâmesi, İstanbul: Kitabevi.

Karabulut, F. \& E. K. ÜrkmeZ (2018). “Türk Dilinin Eskicil Bir Kelimesi Alaçuk: Yapisal Kökenbilimsel Bir Analiz", Littera Turca Journal of Turkish Language and Literature, 4/2: 404-427.

KARGI, Z. (1991). “Şecere-i Terākime'deki Manzum Parçalar Üzerine”, Türk Dilleri Araştırmaları, 1: 180-197.

KAYDAROV, A. \& M. ORAZOV (2010). Türklük Bilgisine Giriş, İstanbul: Kesit Yayınları.

KIRZıoĞLU, M. F. (2000). Dede Korkut Oğuznâmeleri, Ankara: Atatürk Kültür Merkezi.

KöPRÜLÜ, F. (1980). Türk Edebiyatı Tarihi. İstanbul: Ötüken Neşriyat. 


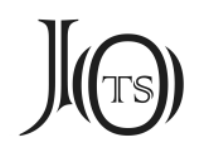

KuanışBayeVA, A. (2002). Formül Nazariyesi ve Koblandı Batır Destanındaki Formüller, Gazi Üniversitesi Sosyal Bilimler Enstitüsü, Ankara. (Yayımlanmamış Yüksek Lisans Tezi)

KYÝASOWA, G. et al. (2016). Türkmen Diliniň Düşündirişli Sözlügi I: A-Ž, Aşgabat: Ylym.

ONAY, A. T. (2000). Eski Türk Edebiyatında Mazmunlar ve İzahı, İstanbul: Akçağ Yayınları.

ÖGEL, B. (2014). Türk Mitolojisi II, Ankara: Türk Tarih Kurumu.

ÖzTÜRK, Ö. (2005). Karadeniz Ansiklopedik Sözlük, İstanbul: Heyemola Yayınları.

PARLATIR, İ. et al. (1998). Türkçe Sözlük, 9. Baskı, Ankara: Türk Dil Kurumu Yayınlar1.

Pehlivan, G. (2014). “Dede Korkut Kitabı'nda Oturma Düzeni Üzerine Yeni Bir Bakış”, Türk Dünyası İncelemeleri Dergisi, 14/2: 205-220.

SAdiQLI, P. (2016). “Mahmud Kaşğari'nin Divanü Lüğat-it-Türk Eserinde Yaşayış Meskenleri”, Tarix, Antropologiya ve Siyasi Élmlər Bakı Avrasiya Universiteti “Sivilizasiya" Jurnal1, 2: 168-172.

SERTKAya, O. F. (2019a). “Dede Korkut Kitabı'nın Kaç Yazma Nüshası Var?”, Türkologiya, 2019/3: 86-93.

SERTKAYA, O. F. (2019b). “AZMUN, Y. Dede Korkut'un Üçüncü Elyazması, Yeni Soylamalar ve Boylar (Hikâyeler) ile Türkmen Sahra Nüshası, Giriş-Metin-Çeviri-SözlükTıpkıbasım, Kutlu Yayınevi, İstanbul, 2019, ss. 176, ISBN: 978-605-7680-06-8”, Journal of Old Turkic Studies, 3/2: 637-646. (Tanitma)

SHAHGOLi, N. K. et al. (2019). “Dede Korkut Kitabi'nın Günbet Yazmasi: İnceleme, Metin, Dizin ve Tıpkıbasım”, Modern Türklük Araştırmaları Dergisi, 16/2: 147-379.

SÜMER, F. (1959). “Oğuzlara Ait Destanî Mahiyette Eserler”, Ankara Üniversitesi Dil ve Tarih-Coğrafya Fakültesi Dergisi, 17/3-4: 359-457.

SÜMER, F. (1999). Oğuzlar (Türkmenler), İstanbul: Türk Dünyası Araştırmaları Vakfi.

TAvKul, U. (2008). "Nart Destanlarının Eski Türk Destanları İle İlişkisi”, Prof. Dr. Ahmet Bican Ercilasun Armağanı, Ed. E. ARIKOĞLU, Akçă̆ Yayınları, Ankara: 599-618. 


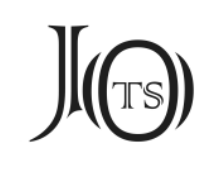

Tufar, N. (2010). Türk Dilinde Meronimi: Organ Adları, Ankara Üniversitesi, Sosyal Bilimler Enstitüsü, Çağdaş Türk Lehçeleri ve Edebiyatları Anabilim Dalı, Ankara. (Yayımlanmamış Doktora Tezi]

Tulum, M. \& M. M. Tulum (2016). Oğuznâmeler, Oğuz Beylerinin Hikâyeleri, Ankara: Atatürk Kültür Merkezi Başkanlığı.

UçAR, E. (2020). “Dede Korkut Kitabı'ndaki Bir Soylama Üzerine”, Eski Türk Edebiyatı Araştırmaları Dergisi, 3/2: 213-240.

URMAnÇAYEv, F. (2016). “Ak Kubek (Ak Köpük) Kahramanlık Efsanesi”, Çev. B. OKKALI, Türk Dünyası Dil ve Edebiyat Dergisi, 41: 185-201. 